\title{
CALIBRATION OF THE HARGREAVES-SAMANI EQUATION FOR SPECIFIC PERIODS OF THE YEAR IN THE MUNICIPALITY OF JAÍBA-MG, BRAZIL
}

Anunciene Barbosa Duarte ${ }^{1}$, Lucas Borges Ferreira² \& Edson Fagne dos Santos ${ }^{3}$

1 - Engenheira Agrônoma, Mestranda em Fitotecnia - UFV, Viçosa-MG, cieneduarte@live.com

2 - Engenheiro Agrônomo, Mestrando em Engenharia Agrícola - UFV, Viçosa-MG, contato.lucasbf@gmail.com

3 - Engenheiro Agrônomo, Mestrando em Produção vegetal no semiárido - UNIMONTES, Janaúba-MG, fagner-edson07@hotmail.com

\section{Keywords:}

agrometeorology

evapotranspiration

irrigation scheduling

temperature

\section{ABSTRACT}

Reference evapotranspiration $\left(\mathrm{ET}_{0}\right)$ explains the climatic effects on crop water demand. The Food and Agriculture Organization (FAO) recommends the Penman Monteith equation as a standard method for estimating $\mathrm{ET}_{0}$. However, because this equation requires a large amount of meteorological data, it has limited application. An alternative is the Hargreaves-Samani (HS) equation, which only requires air temperature data, and can be calibrated to specific locations and periods. The present study aimed to calibrate the empirical parameters (coefficients and exponent) of the HS equation for specific periods of the year, as well as evaluate the behavior and calibration of this equation throughout the year in the municipality of Jaíba-MG, Brazil. The daily meteorological data from 1996 to 2011 were gathered from a weather station located in the municipality of Jaíba-MG. A general calibration and calibrations by semester, by season, by month and for periods with similar climatic conditions was performed. The calibration of the HS equation, in all of the forms studied, promoted better $\mathrm{ET}_{0}$ estimations. The calibrations for specific periods of the year only promoted slight increases in performance in relation to the general calibration, therefore they, in general, presented equal performance to each other.

\section{Palavras-chave:} agrometeorologia evapotranspiração manejo da irrigação temperatura

\section{CALIBRAÇÃO DA EQUAÇÃO DE HARGREAVES-SAMANI PARA PERÍODOS ESPECÍFICOS DO ANO NO MUNICÍPIO DE JAÍBA-MG}

\section{RESUMO}

A evapotranspiração de referência $\left(\mathrm{ET}_{0}\right)$ explica os efeitos climáticos na demanda hídrica das culturas. A equação de Penman-Monteith, é recomendada pela Food and Agriculture Organization (FAO) como um método padrão para estimativa da $\mathrm{ET}_{0}$. No entanto, por requerer grande quantidade de dados meteorológicos, tem sua aplicação limitada. Uma alternativa é a equação de Hargreaves-Samani (HS), que requer apenas dados de temperatura do ar, podendo ser calibrada para locais e períodos específicos. Objetivou-se com o presente estudo calibrar os parâmetros empíricos (coeficientes e expoente) da equação de HS para períodos específicos do ano, bem como avaliar o comportamento desta e suas calibrações ao longo do ano no município de Jaíba-MG, Brasil. Utilizou-se dados meteorológicos diários do período de 1996 a 2011 de uma estação meteorológica situada no município de Jaíba-MG. Realizou-se uma calibração geral, por semestre, por estação do ano, por mês e para períodos com condições climáticas similares. A calibração da equação de HS, em todas as formas estudadas, promoveu melhores estimativas da $\mathrm{ET}_{0}$. As calibrações da equação de Hargreaves-Samani para períodos específicos do ano promoveram apenas ligeiros aumentos de performance em relação a calibração geral, obtendo, por via de regra, igual performance. 


\section{INTRODUCTION}

The evapotranspiration represents the water loss to the atmosphere from the evaporation and transpiration processes. It is a variable of extreme importance for irrigation scheduling and planning, hydrological studies, crop yield prediction, among others (PERERA et al., 2015; ANTONOPOULOS \& ANTONOPOULOS, 2017). However, its determination is not easy, given the dependence of the soil moisture, type of crop and climate conditions.

For convenience, ALLEN et al. (1998) defined the concept of reference evapotranspiration $\left(\mathrm{ET}_{0}\right)$ and it can be determined through meteorological data and subsequently adjusted to the crop of interest. According to CAMMALLERI et al. (2013) the $\mathrm{ET}_{0}$ assumes an essential role since it explains the climatic effects on the water demand of the crops, proving an important key for irrigation planning.

The Food and Agriculture Organization (FAO) proposed the use of the Penman-Monteith (PM) method for estimating $\mathrm{ET}_{0}$ (ALLEN et al., 1998), which is recommended as a standard and can be used in any region of the world, without need for local calibration, including to validate other equations.

Although it is an already consolidated and reliable method, PM method requires several meteorological input data, such as air temperature, relative humidity, solar radiation and wind speed. Due to this, the application of this method is limited (PEREIRA et al., 2015; GHAMARNIA et al., 2011; BORGES JÚNIOR et al., 2012; TALAEE, 2014), especially in developing countries, since such parameters are scarce or not available, making it necessary to use alternative methods.

The Hargreaves-Samani (HS) method (HARGREAVES \& SAMANI, 1985) has presented reasonable performance without the requirement of many input meteorological parameters. This is a simple method, basically requiring air temperature data. According to MENDICINO \& SENATORE (2013) the study and development of methods based on temperature is justified by the fact that this is the variable more broadly monitored among those necessary for $\mathrm{ET}_{0}$ estimation.
Despite the reasonable performance, the HS method is more suitable for the place where it is calibrated. PATEL et al. (2015) calibrated the HS equation to locations in India, and verified that the calibration provided an improvement in the method performance.

Given that it is an empirical equation, the HS method presents different responses throughout the year (LIMA JUNIOR et al., 2016; MARTI et al., 2015). In this way, improvements can be obtained by means of specific calibrations for certain periods.

Themunicipality of Jaíbahave a large agricultural center, called Jaíba Irrigation Project, located in the extreme north of Minas Gerais, Brazil. This project has as base the irrigated agriculture, with the fruits cultivation as an important axis, and is the main responsible for promoting the development of the region. Because it is a prominent region in irrigated agriculture, the development of works that aim to adjust parameters for a better irrigation management becomes of great importance.

In this context, the present study aimed to calibrate the empirical parameters of the HS equation for specific periods of the year, as well as to evaluate the behavior of this equation and its calibrations throughout the year in the municipality of Jaíba-MG.

\section{MATERIAL AND METHODS}

The study was conducted using daily data from 1996 to 2011 obtained from a weather station of the Instituto Nacional de Meteorologia (INMET) available at Banco de Dados Meteorológicos para Ensino e Pesquisa (BDMEP). The weather station is located in the municipality of Jaíba-MG, Brazil $\left(15,08^{\circ} \mathrm{S} 44,01^{\circ} \mathrm{W}\right.$ and altitude of $\left.452 \mathrm{~m}\right)$.

We used data of maximum and minimum air temperature, relative humidity, insolation and wind speed. The latter, measured at $10 \mathrm{~m}$ height, was converted to $2 \mathrm{~m}$ height, as recommended by ALLEN et al. (1998).

Once obtained, the data were submitted to a preprocessing, wherein were deleted days with missing data or that had a minimum temperature higher than the maximum, negative insolation or greater than $16 \mathrm{~h}$, negative relative humidity or 
greater than $100 \%$ or wind speed (10 m height) negative or greater than $20 \mathrm{~m} \mathrm{~s}^{-1}$.

The reference evapotranspiration $\left(\mathrm{ET}_{0}\right)$ determined by the Penman Monteith (PM) method (Equation 1) was used as standard for the calibration of the Hargreaves-Samani (HS) equation.

$\mathrm{ET}_{0 \mathrm{PM}}=\frac{0,408 \mathrm{~s}\left(\mathrm{R}_{\mathrm{n}}-\mathrm{G}\right)+\gamma \frac{900}{\mathrm{t}+273} \mathrm{u}_{2}\left(\mathrm{e}_{\mathrm{s}}-\mathrm{e}_{\mathrm{a}}\right)}{\mathrm{s}+\gamma\left(1+0,34 \mathrm{u}_{2}\right)}$

where,

$\mathrm{ET}_{\mathrm{OPM}}=$ reference evapotranspiration calculated by Penman Monteith, $\mathrm{mm} \mathrm{d}^{-1}$;

$\mathrm{R}_{\mathrm{n}}=$ net solar radiation, $\mathrm{MJ} \mathrm{m}^{-2} \mathrm{~d}^{-1}$;

$\mathrm{G}=$ soil heat flux, $\mathrm{MJ} \mathrm{m}^{-2} \mathrm{~d}^{-1}$ (considered as null for daily estimates);

$\mathrm{t}=$ daily mean air temperature, ${ }^{\circ} \mathrm{C}$;

$\mathrm{u}_{2}=$ wind speed at $2 \mathrm{~m}$ height, $\mathrm{m} \mathrm{s}^{-1}$;

$\mathrm{e}_{\mathrm{s}}=$ saturation vapor pressure, $\mathrm{kPa}$

$\mathrm{e}_{\mathrm{a}}=$ actual vapour pressure, $\mathrm{kPa}$;

$\mathrm{s}=$ slope of the saturation vapor pressure function, $\mathrm{kPa}{ }^{\circ} \mathrm{C}^{-1}$, and

$\gamma=$ psychometric constant, $\mathrm{kPa}^{\circ} \mathrm{C}^{-1}$.

The calibration process was performed with data from 1996 to 2005 (10 years) and was based on the adjustment of the empirical parameters of the HS equation (Equation 2). The adjustments were performed using the Microsoft Excel Solver tool employing the nonlinear optimization using the generalized reduced gradient (GRG) method to minimize the mean absolute error (Equation 3). The initial values of the parameters were the original values of the equation, proposed by Hargreaves \& Samani (1985).

$$
\mathrm{ET}_{\text {OHS }}=\mathrm{AR}_{\mathrm{a}}(\mathrm{t}+\mathrm{B})\left(\mathrm{t}_{\max }-\mathrm{t}_{\text {min }}\right)^{\mathrm{C}}
$$

where,

$\mathrm{ET}_{\text {OHS }}=$ reference evapotranspiration calculated by Hargreaves-Samani, $\mathrm{mm} \mathrm{d}^{-1}$;

$\mathrm{A}, \mathrm{B}$ e $\mathrm{C}=$ empirical parameters, standard values: $0.0023,17.8$ e 0.5 , respectively;

$\mathrm{R}_{\mathrm{a}}=$ extraterrestrial radiation, $\mathrm{mm} \mathrm{d}^{-1}$;

$\mathrm{t}_{\max }=$ maximum air temperature, ${ }^{\circ} \mathrm{C}$;

$\mathrm{t}_{\min }=$ minimum air temperature, ${ }^{\circ} \mathrm{C}$, and

$\mathrm{t}=$ mean air temperature, ${ }^{\circ} \mathrm{C}$.
$\mathrm{MAE}=\frac{1}{\mathrm{n}} \sum|\mathrm{HSi}-\mathrm{PMi}|$

where,

MAE $=$ mean absolute error, $\mathrm{mm} \mathrm{d}^{-1}$;

$\mathrm{HS}_{\mathrm{i}}=\mathrm{ET}_{0}$ calculated by Hargreaves-Samani, mm $\mathrm{d}^{-1}$;

$\mathrm{PM}_{\mathrm{i}}=\mathrm{ET}_{0}$ calculated by Penman Monteith, mm $\mathrm{d}^{-1}$, and

$\mathrm{n}=$ number of data pairs.

Specific calibrations were performed for different periods of the year: general calibration, for which a calibration was obtained for use at any time of the year; by semester, specific calibrations were obtained for each semester of the year; by season, specific calibrations were obtained for each season; by month, specific calibrations were obtained for each month; and calibration for periods with similar climatic conditions, calibrations were obtained for sets of months with similar evapotranspiration behavior.

The seasons were considered as follows: summer, months 1, 2 and 3; autumn, months 4, 5 and 6; winter, months 7, 8 and 9; and spring, months 10,11 and 12 . To perform the calibration for periods with similar climatic conditions, first, the monthly mean of the daily $\mathrm{ET}_{0}$ was calculated by PM and HS methods. Subsequently, the ET, behavior estimated by both methods was analyzed throughout the year and, based on this information, the months with similar behavior were grouped. Then, a calibration was performed for each group.

The performances of the original HS equation and its calibrations were measured using data from 2006 to 2011 (6 years), being presented for each month and for the evaluated period as a whole.

For the monthly evaluation, we used the mean absolute error (EAM) and correlation coefficient (r). For the general evaluation, besides the MAE and $r$, the mean bias error (MBE), Willmott's index of agreement (d) and performance index (PI) were used, according to the following equations. The PI was classified according to the criteria proposed by Camargo \& Sentelhas (1997) (Table 1). 
DUARTE, A. B. et al.

$$
\begin{aligned}
& \text { MAE }=\frac{1}{n} \sum|\mathrm{Pi}-\mathrm{Oi}| \\
& \mathrm{MBE}=\frac{1}{\mathrm{n}} \sum(\mathrm{Pi}-\mathrm{Oi}) \\
& \mathrm{d}=1-\left[\frac{\sum(\mathrm{Pi}-\mathrm{Oi})^{2}}{\sum(|\mathrm{Pi}-\overline{\mathrm{O}}|+|\mathrm{Oi}-\overline{\mathrm{O}}|)^{2}}\right] \\
& \mathrm{r}=\frac{\sum(\mathrm{Pi}-\overline{\mathrm{P}})(\mathrm{Oi}-\overline{\mathrm{O}})}{\sqrt{\left(\sum(\mathrm{Pi}-\overline{\mathrm{P}})^{2}\right)\left(\sum(\mathrm{Oi}-\overline{\mathrm{O}})^{2}\right)}} \\
& \mathrm{PI}=\mathrm{r} * \mathrm{~d}
\end{aligned}
$$

where,

$\mathrm{MAE}=$ mean absolute error, $\mathrm{mm} \mathrm{d}^{-1}$;

$\mathrm{MBE}=$ mean bias error, $\mathrm{mm} \mathrm{d}^{-1}$;

$\mathrm{d}=$ Willmott's index of agreement;

$\mathrm{r}=$ correlation coefficient;

$\mathrm{PI}=$ performance index;

$\mathrm{Pi}=$ value predicted by the model, $\mathrm{mm} \mathrm{d}^{-1}$;
$\mathrm{Oi}=$ observed value, $\mathrm{mm} \mathrm{d}^{-1}$;

$\overline{\mathrm{P}}=$ mean of values predicted by the model, $\mathrm{mm} \mathrm{d}^{-1}$;

$\overline{\mathrm{O}}=$ mean of observed values, $\mathrm{mm} \mathrm{d}^{-1}$, and $\mathrm{n}=$ number of data pairs.

Table 1. Classification criteria of the performance index (PI)

\begin{tabular}{cc}
\hline Value of "PI" & Performance \\
\hline$>0.85$ & Great \\
0.76 a 0.85 & Very Good \\
0.66 a 0.75 & Good \\
0.61 a 0.65 & Medium \\
0.51 a 0.60 & Not Good \\
0.41 a 0.50 & Bad \\
$\leq 0.40$ & Terrible \\
\hline
\end{tabular}

Font: Camargo and Sentelhas (1997)

\section{RESULTS AND DISCUSSION}

The coefficients and exponents of the HargreavesSamani (HS) equation calibrated for the periods of the year under study are shown in Table 2.

Table 2. Empirical parameters of the calibrated Hargreaves-Samani equation (A, B and C) for different periods of the year

\begin{tabular}{ccccc}
\hline & & \multicolumn{3}{c}{ Empirical parameter } \\
\hline Calibration & Period & A & B & C \\
\hline General & General & 0.0019 & 11.3551 & 0.5836 \\
\hline \multirow{2}{*}{ Semesters } & Spring/Summer & 0.0016 & 7.9361 & 0.6795 \\
& Fall/Winter & 0.0045 & 13.3250 & 0.2494 \\
\hline \multirow{3}{*}{ Seasons } & Summer & 0.0023 & 0.0000 & 0.6383 \\
& Fall & 0.0045 & 7.8478 & 0.3004 \\
& Winter & 0.0053 & 15.6691 & 0.1744 \\
& Spring & 0.0014 & 7.8465 & 0.7227 \\
\hline \multirow{4}{*}{ Months } & January & 0.0019 & 0.0000 & 0.7171 \\
& February & 0.0013 & 25.7556 & 0.5974 \\
& March & 0.0015 & 10.6345 & 0.6783 \\
& April & 0.0027 & 15.8436 & 0.4123 \\
& May & 0.0046 & 9.8718 & 0.2651 \\
& June & 0.0050 & 10.4445 & 0.2373 \\
& July & 0.0049 & 38.3001 & 0.0236 \\
& August & 0.0044 & 52.7209 & 0.0000 \\
& September & 0.0011 & 109.2799 & 0.3299 \\
& October & 0.0016 & 12.4670 & 0.6082 \\
& November & 0.0008 & 17.7407 & 0.8218 \\
& December & 0.0009 & 20.1192 & 0.7675 \\
\hline \multirow{3}{*}{ Climatic groups } & Summer & 0.0023 & 0.0000 & 0.6383 \\
& Fall/Winter & 0.0045 & 13.3250 & 0.2494 \\
& Spring & 0.0014 & 7.8465 & 0.7227 \\
\hline
\end{tabular}


For general calibration were obtained values of $0.0019,11.3551$ and 0.5836 for the parameters A, B and $C$, respectively. The values of the parameters $A$ and $\mathrm{B}$ were lower than the originals of the equation, 0.0023 and 17.8 , respectively. On the other hand, the value of the parameter $\mathrm{C}(0.5836)$ was higher than the original value $(0.5)$.

For the calibration by semester, the parameters $\mathrm{A}, \mathrm{B}$ and $\mathrm{C}$ showed large differences between the semesters. For the first semester (Spring/Summer) these presented values equal to $0.0016,7.9361$ and 0.6795 , respectively. For the second semester (Fall/ Winter), the same parameters presented respective values of $0.0045,13.3250$ and 0.2494. BORGES JÚNIOR et al. (2012) studying the calibration of the Hargreaves-Samani method for Garanhuns-PE (Brazil) obtained values of $0.0013,17.76$ and 0.76 ( $\mathrm{A}, \mathrm{B}$ and $\mathrm{C}$ respectively) for the spring-summer semester and $0.0014,17.79$ and $0.70(\mathrm{~A}, \mathrm{~B}$ and $\mathrm{C}$ respectively), for the fall-winter semester.

For the calibration by season there was a variation from 0.0014 (spring) to 0.0053 (winter) for parameter A, from 0.0000 (summer) to 15.6691 (winter) for parameter B and from 0.11744 (winter) to 0.7227 (spring) for parameter C. In view of the results, it can be observed that the spring and winter season were the ones with the most discrepant coefficients to each other.
From the analysis of the Figure 1 is possible to note that the fact that the greatest difference between the values of the parameters of the HS equation was found between spring and winter can be justified by the greater difference between the $\mathrm{ET}_{0}$ behavior estimated by the PM and HS methods verified for these two seasons. During the winter (months 7, 8 and 9) a smaller difference was observed between the $\mathrm{ET}_{0}$ estimated by PM and HS methods in relation to the difference observed in the spring.

For the calibration by month was obtained a variation from 0.0008 (November) to 0.0050 (June) for the parameter A, from 0.0000 (January) to 109.2799 (September) for the parameter B and from 0.0000 (August) to 0.8218 (November) for the parameter $\mathrm{C}$.

From the analysis of $\mathrm{ET}_{0}$ behavior estimated by PM and HS methods presented in Figure 1, a calibration was performed for groups of months with similar climatic characteristics. Three groups were defined, the first with months 1,2 and 3 (summer), the second with months 4, 5, 6, 7, 8 and 9 (fall/winter) and the third with months 10,11 and 12 (spring). These groups were defined based on the difference between the monthly average daily $\mathrm{ET}_{0}$ estimated by PM and HS methods, grouping the months with similar values.

Regarding the above grouping, respective values

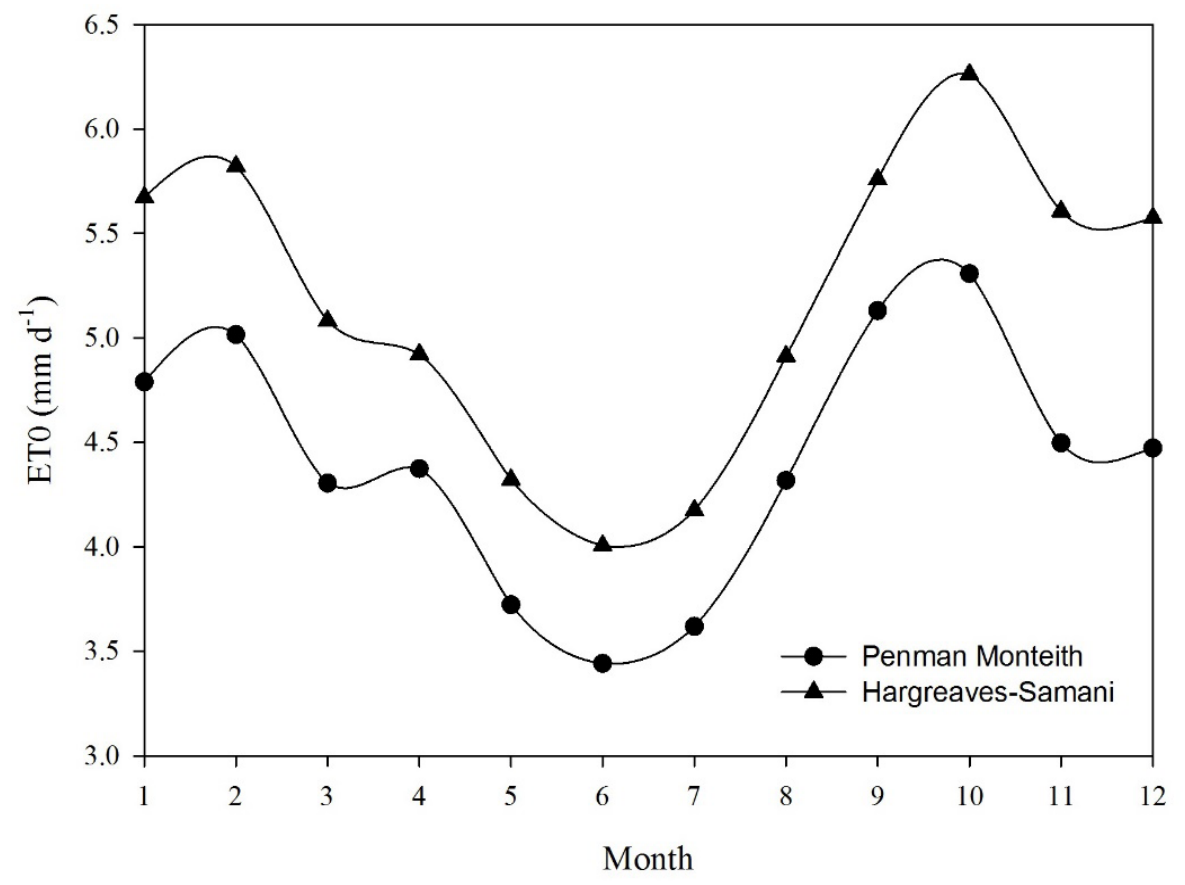

Figure 1. Behavior of the monthly average daily reference evapotranspiration estimated by the Penman Monteith and Hargreaves-Samani equations throughout the year. 
were obtained for parameters A, B and C of 0.0023 , 0.0000 and 0.6383 for the group with months 1,2 and 3 (summer), $0.0045,13.3250$ and 0.2494 for the group with months $4,5,6,7,8$ and 9 (fall/winter) and $0.0014,7.8465$ and 0.7227 for the group with months 10, 11 and 12 (spring).

The results for the different calibrations and for the not calibrated HS equation were analyzed based on the statistical indexes and classification of the performance index, presented in Table 3 .

Evaluating the performance of the HS equation and its calibrations by the mean absolute error (MAE) and the correlation coefficient (r) can be noted that there was a variation of this over the months. This is due to the empirical basis of the method, which, in turn, makes the performance be altered as result of the climatic variations occurred throughout the year. MOELETSI et al. (2013) and MARTÍ et al. (2015) also verified different performances of the HS equation throughout the year.

The not calibrated HS equation presented performance classified as "medium". However, after the calibrations it was possible to obtain a better classification, being classified as "good" for all the

Table 3. Statistical indexes and classification for the Hargreaves-Samani (HS original) equation and its calibrations: general (HS general), by semester (HS semester), by season (HS season), y month (HS month) and by groups with similar climate (HS climate)

\begin{tabular}{|c|c|c|c|c|c|c|c|}
\hline Period & Statistical index & $\begin{array}{c}\text { HS } \\
\text { original }\end{array}$ & $\begin{array}{c}\text { HS } \\
\text { general }\end{array}$ & $\begin{array}{c}\text { HS } \\
\text { semester }\end{array}$ & $\begin{array}{c}\text { HS } \\
\text { season }\end{array}$ & $\begin{array}{c}\text { HS } \\
\text { month }\end{array}$ & $\begin{array}{c}\text { HS } \\
\text { climate }\end{array}$ \\
\hline \multirow{6}{*}{ General } & $\mathrm{r}$ & 0.83 & 0.82 & 0.84 & 0.84 & 0.83 & 0.84 \\
\hline & $\operatorname{MAE}\left(\mathrm{mm} \mathrm{d}^{-1}\right)$ & 0.94 & 0.53 & 0.49 & 0.48 & 0.47 & 0.48 \\
\hline & $\operatorname{MBE}\left(\mathrm{mm} \mathrm{d}^{-1}\right)$ & 0.90 & 0.25 & 0.19 & 0.15 & 0.10 & 0.16 \\
\hline & $\mathrm{d}$ & 0.78 & 0.89 & 0.90 & 0.90 & 0.90 & 0.90 \\
\hline & $\mathrm{C}$ & 0.64 & 0.73 & 0.75 & 0.75 & 0.75 & 0.75 \\
\hline & Classification & Medium & Good & Good & Good & Good & Good \\
\hline \multirow[t]{2}{*}{ January } & $\mathrm{r}$ & 0.80 & 0.80 & 0.80 & 0.79 & 0.79 & 0.79 \\
\hline & $\operatorname{MAE}\left(\mathrm{mm} \mathrm{d}^{-1}\right)$ & 0.92 & 0.50 & 0.51 & 0.51 & 0.51 & 0.51 \\
\hline \multirow[t]{2}{*}{ February } & $\mathrm{r}$ & 0.81 & 0.81 & 0.81 & 0.81 & 0.81 & 0.81 \\
\hline & $\operatorname{MAE}\left(\mathrm{mm} \mathrm{d}^{-1}\right)$ & 1.00 & 0.55 & 0.52 & 0.52 & 0.53 & 0.52 \\
\hline \multirow[t]{2}{*}{ March } & $\mathrm{r}$ & 0.75 & 0.75 & 0.75 & 0.76 & 0.75 & 0.76 \\
\hline & $\operatorname{MAE}\left(\mathrm{mm} \mathrm{d}^{-1}\right)$ & 0.86 & 0.50 & 0.49 & 0.48 & 0.49 & 0.48 \\
\hline \multirow[t]{2}{*}{ April } & $\mathrm{r}$ & 0.78 & 0.78 & 0.74 & 0.76 & 0.78 & 0.74 \\
\hline & $\operatorname{MAE}\left(\mathrm{mm} \mathrm{d}^{-1}\right)$ & 0.67 & 0.36 & 0.48 & 0.43 & 0.39 & 0.48 \\
\hline \multirow[t]{2}{*}{ May } & $\mathrm{r}$ & 0.72 & 0.72 & 0.68 & 0.69 & 0.68 & 0.68 \\
\hline & $\operatorname{MAE}\left(\mathrm{mm} \mathrm{d}^{-1}\right)$ & 0.76 & 0.36 & 0.40 & 0.36 & 0.35 & 0.40 \\
\hline \multirow[t]{2}{*}{ June } & $\mathrm{r}$ & 0.23 & 0.22 & 0.25 & 0.24 & 0.24 & 0.25 \\
\hline & $\operatorname{MAE}\left(\mathrm{mm} \mathrm{d}^{-1}\right)$ & 0.71 & 0.40 & 0.36 & 0.33 & 0.34 & 0.36 \\
\hline \multirow[t]{2}{*}{ July } & $\mathrm{r}$ & 0.50 & 0.50 & 0.54 & 0.54 & 0.49 & 0.54 \\
\hline & $\operatorname{MAE}\left(\mathrm{mm} \mathrm{d}^{-1}\right)$ & 0.92 & 0.51 & 0.42 & 0.44 & 0.37 & 0.42 \\
\hline \multirow[t]{2}{*}{ August } & $\mathrm{r}$ & 0.17 & 0.14 & 0.30 & 0.34 & 0.45 & 0.30 \\
\hline & $\operatorname{MAE}\left(\mathrm{mm} \mathrm{d}^{-1}\right)$ & 0.98 & 0.62 & 0.48 & 0.48 & 0.43 & 0.48 \\
\hline \multirow[t]{2}{*}{ September } & $\mathrm{r}$ & 0.39 & 0.38 & 0.33 & 0.29 & 0.41 & 0.33 \\
\hline & $\operatorname{MAE}\left(\mathrm{mm} \mathrm{d}^{-1}\right)$ & 1.07 & 0.70 & 0.58 & 0.59 & 0.69 & 0.58 \\
\hline \multirow[t]{2}{*}{ October } & $\mathrm{r}$ & 0.84 & 0.84 & 0.84 & 0.84 & 0.84 & 0.84 \\
\hline & $\operatorname{MAE}\left(\mathrm{mm} \mathrm{d}^{-1}\right)$ & 0.90 & 0.56 & 0.56 & 0.56 & 0.59 & 0.56 \\
\hline \multirow[t]{2}{*}{ November } & $\mathrm{r}$ & 0.85 & 0.85 & 0.85 & 0.85 & 0.85 & 0.85 \\
\hline & $\operatorname{MAE}\left(\mathrm{mm} \mathrm{d}^{-1}\right)$ & 1.32 & 0.73 & 0.65 & 0.60 & 0.55 & 0.60 \\
\hline \multirow[t]{2}{*}{ December } & $\mathrm{r}$ & 0.89 & 0.89 & 0.89 & 0.89 & 0.89 & 0.89 \\
\hline & $\operatorname{MAE}\left(\mathrm{mm} \mathrm{d}^{-1}\right)$ & 1.12 & 0.58 & 0.48 & 0.45 & 0.46 & 0.45 \\
\hline
\end{tabular}


studied calibrations.

It should be noted that all calibrations promoted better performance in $\mathrm{ET}_{0}$ estimation, which can be evidenced by the reduction of the MAE and mean bias error (MBE) and increase of Willmott's index of agreement (d) and performance index (PI), besides the improvement in the classification. These results indicate that the local calibration improved the performance of the HS equation, corroborating with GAO et al. (2014) and ARRAES et al. (2016). Although the good results obtained with the calibrations, it is important to highlight that in some months, especially in September, the calibrated models presented lower values of $r$, however, even with lower precision the calibrated models presented lower MAE values.

Evaluating the behavior of the calibrations under study it was noticed that the performance of all was close, being these classified as "good". However, having the general calibration as reference, there was a slight gain in performance when using calibrations for specific periods of the year (calibration by semester, by season, by month and for groups with similar climate).
Analyzing only the calibrations for specific periods it is possible to note that the reduction of the period used in the calibration did not promote significant performance gains. Thus, the use of the calibration by semester was enough to obtain a slight gain of performance in relation to the general calibration. BORGES JUNIOR et al. (2017), also did not obtain significant gains by reducing the specificity period of the calibration.

The results obtained in the present study contradict in part the idea presented by MARTÍ et al. (2015), that when checking different behaviors of the HS equation throughout the year, suggested that more efficient calibrations could be achieved by obtaining calibration parameters for monthly periods or at least for each season.

The analysis of the Figure 2 shows the above mentioned performance gain from the evaluated calibrations, as well as the slight gain obtained with the calibrations for specific periods in relation to the general calibration, represented in the graph by the calibration by semester, given it presented performance almost equal to the other calibrations for specific periods.

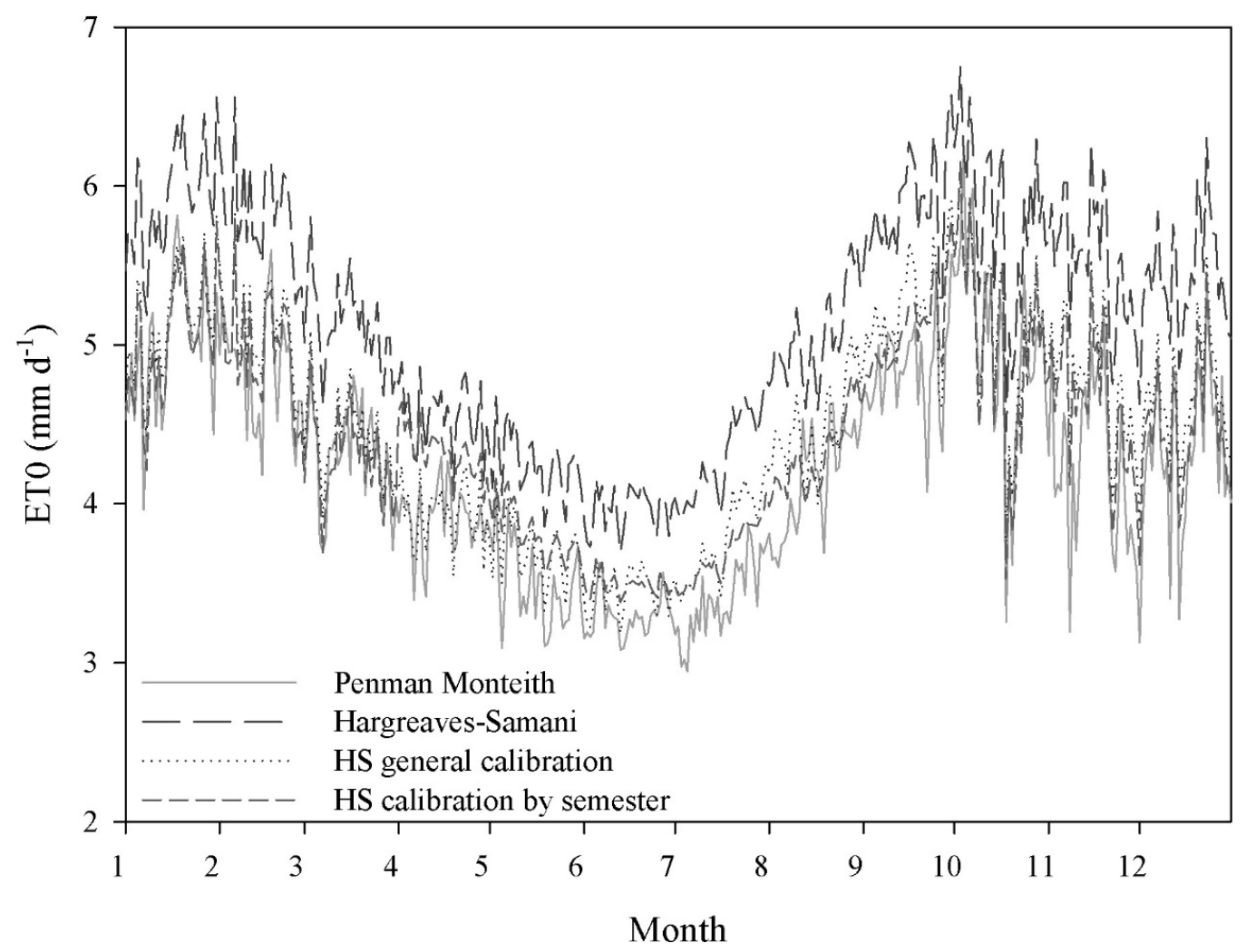

Figure 2. Mean behavior of the daily reference evapotranspiration throughout the year estimated by the Penman Monteith, Hargreaves Samani and its general and by semester calibrations for the municipality of Jaíba-MG. 


\section{CONCLUSIONS}

- The Hargreaves-Samani equation in its original and calibrated forms presented performance varying throughout the year in response to the climatic variations.

- The calibration of the Hargreaves-Samani equation, in all studied ways, promoted better estimates of reference evapotranspiration in relation to the original equation.

- The calibrations for specific periods of the year only promoted slight performances improvements in relation to the general calibration, obtaining, in general, equal performances between them.

\section{ACKNOWLEDGMENTS}

To the National Council for Scientific and Technological Development (CNPq) for the financial support.

\section{REFERENCES}

ALLEN, R.G.; PEREIRA, L.S.; RAES, D.; SMITH, M. Crop evapotranspiration: Guidelines for computing crop water requirements. Rome: FAO, 1998. 300p. (FAO - Irrigation and Drainage Paper, 56).

ANTONOPOULOS, VASSILIS Z; ANTONOPOULOS, ATHANASIOS V. Daily reference evapotranspiration estimates by artificial neural networks technique and empirical equations using limited input climate variables. Computers and Electronics in Agriculture, New York, v.132, n.1, p.86-96, 2017.

ARRAES, F.D.D., LIMA JUNIOR, J.C., OLIVEIRA, J.B., MACEDO, K.G., COURAS, Y.S.; OLIVEIRA, W.C. Parametrização da equação de Hargreaves-Samani para o estado do Pernambuco-Brasil. Revista Brasileira de Agricultura Irrigada, Fortaleza, v.10, n.1, p.410419, 2016.

BORGES JÚNIOR, J.C.F., OLIVEIRA, A.L.M.,
ANDRADE, C.D.L.T., \&PINHEIRO, M.A.B. Equação de Hargreaves-Samani calibrada em diferentes bases temporais para Sete Lagoas, MG. Engenharia na Agricultura, Viçosa, v.25, n.1, p.38-49, 2017.

BORGES JÚNIOR, J.C.F.; ANJOS, R.J.; SILVA, T.J.A.; LIMA, J.R.S.; ANDRADE, C.L.T. Métodos de estimativa da evapotranspiração de referência diária para a microrregião de Garanhuns, PE. Revista Brasileira de Engenharia Agrícola e Ambiental, Campina Grande, v.16, n.4, p.380390, 2012.

CAMARGO, Â.P., SENTELHAS, P.C. Avaliação do desempenho de diferentes métodos de estimativa da evapotranspiração potencial no estado de São Paulo. Revista Brasileira de Agrometeorologia, Santa Maria, v.5, n.1, p.89-97, 1997.

CAMMALLERI, C., CIRAOLO, G.; MINACAPILLI, M.; RALLO, G. Evapotranspiration from an Olive Orchard Using Remote Sensing-Based Dual Crop Coefficient Approach. Water Resources Management, v.27, n.14, p.4877-4895, 2013.

GAO, X.; PENG, X.; XU, J.; YANG, S.; WANG, W. Proper Methods and Its Calibration for Estimating Reference Evapotranspiration Using Limited Climatic Data in Southwestern China. Archives of Agronomy and Soil Science, v.61, n.3, p.415-426, 2014.

GHAMARNIA, H.; REZVANI, V.; KHODAEI, E.; MIRZAEI, H. Time and Place Calibration of the Hargreaves Equation for Estimating Monthly Reference Evapotranspiration under Different Climatic Conditions. Journal of Agricultural Science, v.4, n.3, p.111-122, 2011.

HARGREAVES, G.H.; SAMANI, Z.A. Reference crop evapotranspiration from temperature. Applied Engineering in Agriculture, Michigan, v.1, n.2, p.96-99, 1985.

LIMA JUNIOR, J.C.; ARRAES, F.D.D.; OLIVEIRA, J.B.; NASCIMENTO, F.A.L.; 
CALIBRATION OF THE HARGREAVES-SAMANI EQUATION FOR SPECIFIC PERIODS OF THE YEAR IN THE...

MACÊDO, K.G. Parametrização da equação de Hargreaves e Samani para estimativa da evapotranspiração de referência no Estado do Ceará, Brasil. Revista Ciência Agronômica, Fortaleza, v.47, n.3, p.447-454, 2016.

MARTÍ, P.; ZARZO, M.; VANDERLINDEN, K.; GIRONA, J. Parametric expressions for the adjusted Hargreaves coefficient in Eastern Spain. Journal of Hydrology, Amsterdam, v.529, n.3, p.1713-1724, 2015.

MENDICINO, G.; SENATORE,A. Regionalization of the Hargreaves coefficient for the assessment of distributed reference evapotranspiration in Southern Italy. Journal of Irrigation and Drainage Engineering, v.139, n.5, p.349-362, 2013.

MOELETSI, M.E.; WALKER, S.; HAMANDAWANA, $\mathrm{H}$. Comparison of the Hargreaves and Samani equation and the Thornthwaite equation for estimating dekadal evapotranspiration in the Free State Province,
South Africa. Physics and Chemistry of the Earth, v.66, n.1, p.4-15, 2013.

PATEL, J.; PATEL, H.; BHATT, C. Modified Hargreaves Equation for Accurate Estimation of Evapotranspiration of Diverse Climate Locations in India. Proceedings of the National Academy of Sciences, India, v.85, n.1, p.161-166, 2015.

PEREIRA, L.S.; ALLEN, R.G.; SMITH, M.; RAES, D. Crop evapotranspiration estimation with FAO56: Past and future. Agricultural Water Management, New York, v.147, n.1, p.4-20, 2015.

PERERA, K.C.; WESTERN, A.W.; NAWARATHNA, B.; GEORGE, B. Comparison of hourly and daily reference crop evapotranspiration equations across seasons and climate zones in Australia. Agricultural Water Management, New York, v.148, n.1, p.84-96, 2015.

TALAEE, P.H. Performance evaluation of modified versions of Hargreaves equation across a wide range of Iranian climates. Meteorology and Atmospheric Physics, v.126, n.1-2, p.65-70, 2014. 